\title{
Size distributions of atmospheric particulate matter and associated trace metals in the multi-industrial city of Ulsan, Korea
}

\author{
Hye-Ok Kwon ${ }^{1}$, Min-Kyu Park ${ }^{1}$, Seong-Joon Kim¹, Jinsoo Choi ${ }^{2}$, Jun $\mathrm{Oh}^{2}$, Joon-Young $\mathrm{Ahn}^{2}$, \\ Sung-Deuk Choi ${ }^{{ }^{+}}$ \\ ${ }^{1}$ School of Urban and Environmental Engineering, Ulsan National Institute of Science and Technology (UNIST), Ulsan 44919, Republic of Korea \\ ${ }^{2}$ Climate and Air Quality Research Department, National Institute of Environmental Research, Incheon 22689, Republic of Korea
}

\begin{abstract}
Particulate matter (PM) was collected using micro-orifice uniform deposit impactors from a residential (RES) site and an industrial (IND) site in Ulsan, South Korea, in September-October 2014. The PM samples were measured based on their size distributions (11 stages), ranging from $0.06 \mu \mathrm{m}$ to over $18.0 \mu \mathrm{m}$. Nine trace metals (As, Se, Cr, V, Cd, Pb, Ba, Sb, and Zn) associated with PM were analyzed. The PM samples exhibited weak bimodal distributions irrespective of sampling sites and events, and the mean concentrations of total PM (TPM) measured at the IND site $\left(56.7 \mu \mathrm{g} / \mathrm{m}^{3}\right)$ was higher than that measured at the RES site $\left(38.2 \mu \mathrm{g} / \mathrm{m}^{3}\right)$. The IND site also showed higher levels of nine trace metals, reflecting the influence of industrial activities and traffic emissions. At both sites, four trace metals (Ba, Zn, V, and Cr) contributed to over $80 \%$ of the total concentrations in TPM. The modality of individual trace metals was not strong except for $\mathrm{Zn}$; however, the nine trace metals in $\mathrm{PM}_{2.5}$ and $\mathrm{PM}_{10}$ accounted for approximately $50 \%$ and $90 \%$ of the total concentrations in TPM, respectively. This result indicates that the size distributions of PM and trace metals are important to understand how respirable PM affects public health.
\end{abstract}

Keywords: Metal, MOUDI, Particulate matter, Size distribution, Ulsan

\section{Introduction}

Suspended solid particles and/or liquid droplets in the atmosphere are known as particulate matter (PM), which are of great environmental concern associated with air quality and public health. PM can be classified into nano, ultrafine, fine, coarse, and super coarse particles according to their aerodynamic diameter, e.g., particles with diameters exceeding $2.5 \mu \mathrm{m}$ and those with diameters below $2.5 \mu \mathrm{m}$ are classified as coarse and fine particles, respectively [1]. On the basis of the characteristics of the source, PM can be classified as natural and anthropogenic, and these can be further divided into two major groups: primary and secondary particles. Soil dust, ocean, volcano, and forest fire are designated as natural sources [2-6], whereas traffic, industrial activities, coal combustion, and incineration are major anthropogenic sources $[7,8]$ responsible for primary particles. In addition, the formation of secondary inorganic and organic aerosol through chemical reactions and physical processes is also important $[9,10]$.
It is known that the size distribution of PM is strongly affected by the type of sources [11].

Owing to various emission sources and size-distribution patterns, PM has different physicochemical properties, which ultimately affects the aerosol composition and alters ambient-air quality [12]. The size distribution and composition of PM are closely related to public health because mortality and morbidity are strongly related to PM exposure. For instance, numerous epidemiological studies have reported significant correlations between adverse health effects and PM uptake via respiratory deposition [13, 14]. Fine particles are particularly hazardous to public health because they can penetrate into the bloodstream through the alveoli [13, 15]. Sub-micrometer-size particles (below $1 \mu \mathrm{m}$ in diameter: $\mathrm{PM}_{1.0}$ ) have a higher probability of depositing deeper in the respiratory tract compared with super-micrometer-size particles [16]. In addition, PM adversely affects vulnerable groups (i.e., children and elderly people) with low-level immunity, and toxic substances associated with PM can induce various respiratory and other dis-
This is an Open Access article distributed under the terms of the Creative Commons Attribution Non-Commercial License (http://creativecommons.org/licenses/by-nc/3.0/) which permits unrestricted non-commercial use, distribution, and reproduction in any medium, provided the original work is properly cited.

Copyright (C) 2019 Korean Society of Environmental Engineers
Received July 8, 2018 Accepted August 31, 2018

${ }^{\dagger}$ Corresponding author

Email: sdchoi@unist.ac.kr

Tel: +82-52-217-2811 Fax: +82-52-217-2859

ORCID: 0000-0003-1024-2620 
eases upon inhalation [13]. PM is composed of diverse substances, such as organic compounds, elemental carbon, ions, and trace metals [17-20]. Among them, toxic metals (e.g., Pb, Cr, Cd, and As) in PM can pose dangerous risks for public health. Hence, monitoring PM levels, their size distribution, and trace metals is essential, particularly in heavily industrial areas.

Ulsan is the largest industrial city in South Korea and has a population of over 1.1 million. It is called the industrial capital of South Korea because it hosts large-scale petrochemical, non-ferrous, automobile, and shipbuilding and heavy industrial complexes. Because they are located close to residential areas, their impact on air quality is a major environmental concern. According to the data from the national heavy metal monitoring network in Korea, the highest level of $\Sigma_{9}$ metals in $\mathrm{PM}_{10}$ was observed in Ulsan [21]. Even though the main industries in Ulsan are believed to be an important source of PM and trace metals, only limited studies have looked at the size distribution of PM and associated trace metals in urban residential areas in Ulsan [22, 23].

In this study, PM samples were collected at an industrial (IND) site and a residential (RES) site in Ulsan using micro-orifice uniform deposit impactors (MOUDIs), and trace metals were analyzed. The contamination characteristics at both sites were compared, and the possible emission sources were discussed based on size distribution and the levels of PM and trace metals. This study is the first one that used MOUDIs and reports the highest particle-size resolution data in Ulsan.

\section{Materials and Methods}

\subsection{Sampling Sites and Methods}

PM samples were collected simultaneously at an IND site and a RES site (Fig. 1) in September (1, 6, 8, 15, 16, 20, and 22) and October (22, 25, and 29) 2014 ( $\mathrm{n}=10)$. The sampling days were selected to reflect a normal local pollution condition in Ulsan. For example, winter and spring exhibit strong effects of long-range transport of Asian dust and smog episodes in Northern China. In summer, decreased fossil fuel burning and frequent precipitation result in relatively low PM concentrations. The IND site was located near a petrochemical complex, and the RES site was located at the center of a residential area $(6.6 \mathrm{~km}$ from the IND site). Meteorological data were collected from automatic weather stations (AWS) operated by the Korea Meteorological Administration (KMA).

The PM samples were simultaneously collected using two MOUDIs (110R, MSP Corp, USA) with Zeflour filters (PTFE, 47 $\mathrm{mm}, 2.0 \mu \mathrm{m}$, Pall Corp, USA) at the two sampling sites. The flow rate of the MOUDIs was $30 \mathrm{~L} / \mathrm{min}$, and they were operated over $24 \mathrm{~h}$ periods, starting at 14:00. Particles in 11 size fractions (inlet and 10 stages) were collected: sub-micrometer size (0.06-0.10, $0.10-0.18,0.18-0.32,0.32-0.56$, and $0.56-1.00 \mu \mathrm{m})$ and super-micrometer size (1.00-1.80, 1.80-3.20, 3.20-5.60, 5.60-10.0, 10.0-18.0, and over $18.0 \mu \mathrm{m})$. The filters were stored in a desiccator for $48 \mathrm{~h}$ to maintain constant relative humidity $(\mathrm{RH})$ and temperature ( $45 \%$ and $24^{\circ} \mathrm{C}$ ) conditions before collecting PM samples. Field blanks were collected from all sampling events at both sampling sites $(\mathrm{n}=20)$.

\subsection{Instrumental Analysis}

The filters were pre-weighed using a high-precision microbalance (XP6 microbalance, Mettler-Toledo, Germany, precision $=1 \mu \mathrm{g}$ ). After the sampling, the filters were reweighed, and then each filter was divided into four segments. To extract trace metals, filter segments (i.e., one-quarter of each filter) were immersed
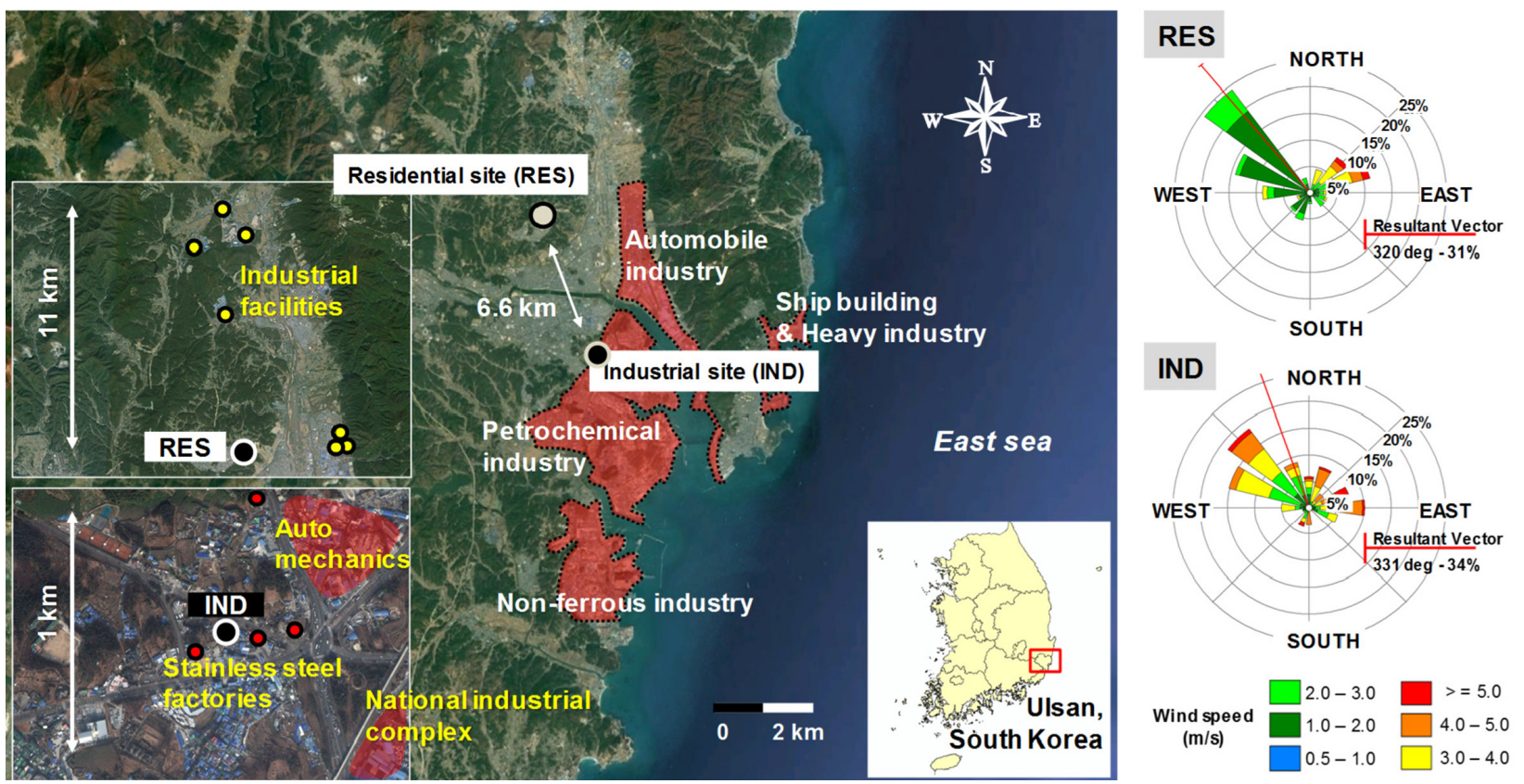

Fig. 1. Locations of two sampling sites and wind patterns during sampling events in Ulsan, Korea. Red areas indicate industrial complexes. 
into $14 \mathrm{~mL}$ of $\mathrm{HCl}$ with $\mathrm{HNO}_{3}$ (v/v 3:1) in Teflon vessels and digested using a graphite digestion (heating plate) system (Odlab, OD-98-002P, Korea) at $200^{\circ} \mathrm{C}$ for $2 \mathrm{~h}$. After cooling under ambient temperature for $30 \mathrm{~min}$, the digested samples were diluted with ultrapure water $\left(18.2 \mathrm{M} \Omega \mathrm{cm}\right.$ at $25^{\circ} \mathrm{C}$, Barnstead GenPure $\times$ CAD Plus, Thermo Scientific, USA) to prepare a final volume of $50 \mathrm{~mL}$ and then stored in a refrigerator at $4^{\circ} \mathrm{C}$ prior to instrumental analysis.

Trace metals were analyzed using an inductively coupled plasma-mass spectrometer (ICP-MS) (ELAN DRC-e, PerkinElmer, USA). The target metals were arsenic (As), selenium (Se), chromium (Cr), vanadium (V), cadmium (Cd), lead (Pb), barium $(\mathrm{Ba})$, stibium (Sb), and zinc (Zn), which were selected based on the detection frequency and levels, toxicity, human health risk, and for local-source identification requested by the Youngnam intensive monitoring station in Ulsan. The extracts were introduced at a rate of $1 \mathrm{~mL} / \mathrm{min}$, and the $\mathrm{RF}$ power was $1,150 \mathrm{~W}$. The flow rates of coolant gas, auxiliary gas, and nebulizer gas were 18.0, 1.00 , and $0.92 \mathrm{~L} / \mathrm{min}$, respectively.

For QA/QC, method blanks were analyzed after every extraction batch $(n=7)$ to confirm the contamination during the experiment, and the analytical data were blank corrected. Method detection limits (MDLs) were calculated by the product of the standard deviations of seven replicates of spiked filter blank samples and the Student's $t$-value $(t=3.14)$ at a 99\% confidence level. The MDL values ranged from $0.04 \mathrm{ng} / \mathrm{m}^{3}$ to $0.74 \mathrm{ng} / \mathrm{m}^{3}$. A standard reference material (SRM-2783, urban dust, NIST, USA) was used to check accuracy and precision. The results $(n=3)$ were satisfactory with a mean recovery of $94.6 \%$ and a mean relative standard deviation of $4.7 \%$.

\section{Results and Discussion}

\subsection{Total Particulate Matter}

The concentrations of total PM (TPM) (i.e., the sum of 11 stage concentrations) ranged from 38.3 to $66.7 \mu \mathrm{g} / \mathrm{m}^{3}$ (mean: $56.7 \mu \mathrm{g} / \mathrm{m}^{3}$, median: $59.6 \mu \mathrm{g} / \mathrm{m}^{3}$ ) at the IND site and from 22.5 to $57.1 \mu \mathrm{g} / \mathrm{m}^{3}$ (mean: $38.2 \mu \mathrm{g} / \mathrm{m}^{3}$, median: $42.5 \mu \mathrm{g} / \mathrm{m}^{3}$ ) at the RES site (Table 1 and Fig. 2). The concentrations of TPM at the IND site were about 1.5 times higher than those at the RES site for all sampling events. The TPM concentrations exceeded $50 \mu \mathrm{g} / \mathrm{m}^{3}$ (annual guideline of $\mathrm{PM}_{10}$ in Korea) for all the sampling events (except for the $1^{\text {st }}$ sampling) at the IND site, whereas the RES site showed much lower concentrations below $50 \mu \mathrm{g} / \mathrm{m}^{3}$ for all the events except for the $9^{\text {th }}$ sampling. Similar patterns of $\mathrm{PM}_{2.5}$ and $\mathrm{PM}_{10}$ were also observed in previous studies [1, 3, 24]. The enhanced TPM concentrations at the IND site can be explained by the proximity of emission sources from the petrochemical industrial complex (Fig. 1) and also other industrial facilities (e.g., stainless-steel factories and auto mechanics). In addition, the IND site was located near a large and busy intersection. Previous studies reported positive correlations between traffic volumes and PM concentrations $[25,26]$, suggesting that road dust raise by vehicles is another potential source of PM in our study.

When northern winds were dominant (from the $2^{\text {nd }}$ to $4^{\text {th }}$ sampling events), the mean concentration of TPM at the IND site was 1.7 times greater than the concentration at the RES site. Auto mechanics and urban areas are located north of the IND site. Thus, the enhanced PM concentrations at the IND site might be related to the activities of the auto mechanics and to traffic emissions. In contrast, the concentrations of TPM at the IND and RES sites were similar during $9^{\text {th }}$ and $10^{\text {th }}$ sampling events, which can be attributed to dominant southern winds during these samplings events from the industrial complexes and main roads.

\subsection{Size Distribution of Particulate Matter}

The modality of particle size distribution is an important parameter to develop air quality guidelines [16]. In particular, $\mathrm{PM}_{1.0}$ is strongly related to public health due to its enhanced possibility of deposition in the pulmonary region of the human lung [13]. In this

Table 1. Concentrations of PM in Particle Size Ranges at Industrial (IND) and Residential (RES) Sites in Ulsan, South Korea

\begin{tabular}{|c|c|c|c|c|c|c|c|c|c|}
\hline \multirow{2}{*}{\multicolumn{2}{|c|}{ Size distribution $(\mu \mathrm{m})$}} & \multicolumn{4}{|c|}{ IND $\left(\mu \mathrm{g} / \mathrm{m}^{3}\right)$} & \multicolumn{4}{|c|}{$\operatorname{RES}\left(\mu \mathrm{g} / \mathrm{m}^{3}\right)$} \\
\hline & & Min & Max & Mean \pm SD & Median & Min & $\operatorname{Max}$ & Mean \pm SD & Median \\
\hline \multicolumn{2}{|c|}{$\mathrm{TPM}^{*}$} & 38.3 & 66.7 & $56.7 \pm 8.3$ & 59.6 & 22.5 & 57.1 & $38.2 \pm 12.0$ & 42.5 \\
\hline Stage 1 & $18<$ & 1.56 & 16.8 & $6.99 \pm 4.2$ & 6.59 & 0.59 & 6.34 & $3.18 \pm 2.2$ & 3.02 \\
\hline Stage 2 & $10-18$ & 2.80 & 19.8 & $7.47 \pm 5.2$ & 6.32 & 0.46 & 5.59 & $2.69 \pm 1.5$ & 2.77 \\
\hline Stage 3 & $5.6-10$ & 3.04 & 7.34 & $4.67 \pm 1.5$ & 4.22 & 0.95 & 5.74 & $3.28 \pm 1.6$ & 3.14 \\
\hline Stage 4 & $3.2-5.6$ & 2.49 & 6.50 & $4.18 \pm 1.4$ & 4.06 & 1.15 & 9.02 & $4.50 \pm 2.5$ & 4.57 \\
\hline Stage 5 & $1.8-3.2$ & 2.41 & 6.87 & $4.36 \pm 1.5$ & 4.31 & 0.87 & 7.37 & $3.65 \pm 2.2$ & 3.18 \\
\hline Stage 6 & $1.0-1.8$ & 1.40 & 7.69 & $4.29 \pm 1.7$ & 4.31 & 1.64 & 4.00 & $2.70 \pm 0.8$ & 2.59 \\
\hline Stage 7 & $0.56-1.0$ & 2.44 & 4.84 & $3.68 \pm 1.0$ & 3.61 & 0.28 & 6.67 & $3.17 \pm 1.8$ & 3.02 \\
\hline Stage 8 & $0.32-0.56$ & 3.03 & 9.63 & $5.11 \pm 1.8$ & 4.76 & 0.88 & 7.89 & $4.50 \pm 2.5$ & 4.40 \\
\hline Stage 9 & $0.18-0.32$ & 2.70 & 13.4 & $5.24 \pm 3.3$ & 4.10 & 2.26 & 6.45 & $3.61 \pm 1.4$ & 3.31 \\
\hline Stage 10 & $0.10-0.18$ & 1.74 & 15.6 & $5.70 \pm 3.8$ & 5.46 & 1.67 & 6.63 & $3.75 \pm 1.7$ & 3.50 \\
\hline Stage 11 & $0.056-0.10$ & 2.86 & 9.99 & $5.05 \pm 2.5$ & 3.93 & 0.59 & 7.90 & $3.18 \pm 2.2$ & 2.61 \\
\hline
\end{tabular}

${ }^{*}$ Sum of all stages 


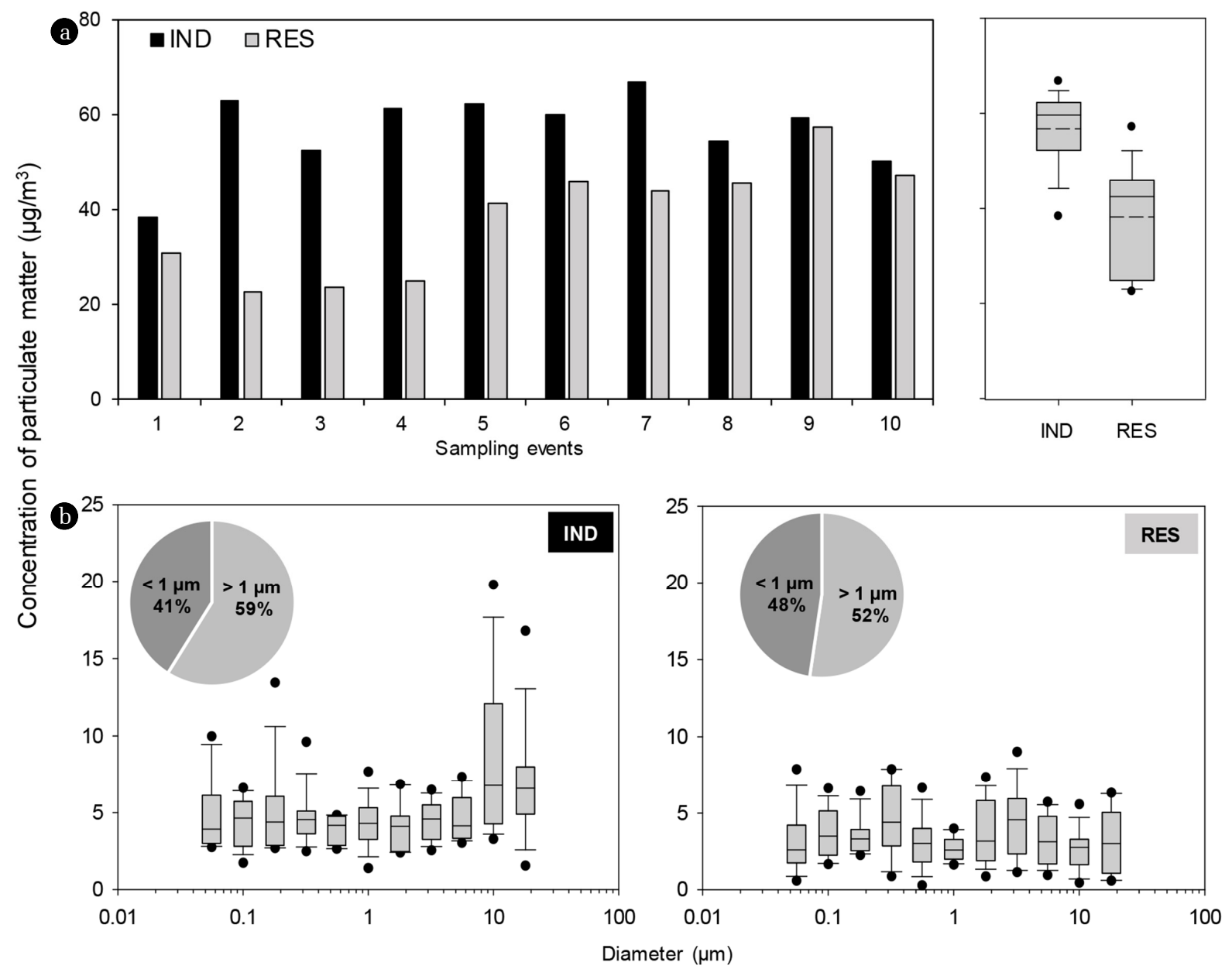

Fig. 2. Concentrations of PM at each sampling site: (a) daily concentrations of TPM (left) and boxplots of TPM concentrations for all sampling events (right) and (b) size distributions of PM.

study, a slight bimodal distribution pattern appeared. At the IND site, the mean concentration of sub-micrometer $(<1 \mu \mathrm{m}) \mathrm{PM}$ (41\%) was less than that of super-micrometer (> $1 \mu \mathrm{m})$ PM (59\%) (Fig. 2(b)). The mean concentrations of PM in the particle-size ranges at the IND site ranged from $3.68 \mu \mathrm{g} / \mathrm{m}^{3}$ in stage $7(0.56-1.0$ $\mu \mathrm{m})$ to $7.47 \mu \mathrm{g} / \mathrm{m}^{3}$ in stage $2(10-18 \mu \mathrm{m})$. The highest mean and median concentrations at the IND site were detected from stage $2(10-18 \mu \mathrm{m})$ and stage $1(>18 \mu \mathrm{m})$, respectively, and the sum of stages 1 and 2 accounted for $25 \%$ of TPM. At the RES site, the mean concentrations of PM ranged from $2.69 \mu \mathrm{g} / \mathrm{m}^{3}$ (stage 2: $10-18 \mu \mathrm{m}$ ) to $4.50 \mu \mathrm{g} / \mathrm{m}^{3}$ (stage $4: 3.2-5.6 \mu \mathrm{m}$ and stage $8: 0.32-0.56$ $\mu \mathrm{m})$. The highest mean concentrations were found at stages 4 and 8 , and the sum of two stages accounted for $24 \%$ of TPM. The mean fractions of sub- and super-micrometer PM at the RES site were similar (48\% and $52 \%$, respectively), representing relatively even distributions of fine and coarse PM. The fractions of super-micrometer PM at the IND site were slightly greater than those at the RES site, possibly due to road dust [27] or sea salt [4]. This issue is further discussed later in this section.

If $\mathrm{PM}_{2.5}$ and $\mathrm{PM}_{10}$ are considered to be collected mostly in stages 5-11 and 2-11, the mean concentrations of $\mathrm{PM}_{10}$ at the IND $\left(49.7 \mu \mathrm{g} / \mathrm{m}^{3}\right)$ and RES $\left(35.0 \mu \mathrm{g} / \mathrm{m}^{3}\right)$ sites were below the regulatory guideline of the 24-h Korean ambient air quality standard $\left(100 \mu \mathrm{g} / \mathrm{m}^{3}\right)$, the World Health Organization (WHO) guideline (50 $\mu \mathrm{g} / \mathrm{m}^{3}$ ), and the US Environmental Protection Agency guideline $\left(150 \mu \mathrm{g} / \mathrm{m}^{3}\right)$. Even though the mean concentration of $\mathrm{PM}_{10}$ at the IND site was similar to the WHO guideline, the levels of $\mathrm{PM}_{10}$ during the $4-7^{\text {th }}$ and $9^{\text {th }}$ sampling events at the IND site and the $9^{\text {th }}$ event at both sites were higher than the WHO guideline. In the case of $\mathrm{PM}_{2.5}$, the mean concentrations at the IND site (33.4 $\left.\mu \mathrm{g} / \mathrm{m}^{3}\right)$ and at the RES site $\left(24.6 \mu \mathrm{g} / \mathrm{m}^{3}\right)$ were slightly higher or similar to the WHO guideline $\left(25 \mu \mathrm{g} / \mathrm{m}^{3}\right)$ and lower than the Korean ambient air quality standard $\left(35 \mu \mathrm{g} / \mathrm{m}^{3}\right)$. Particularly, the concentrations of $\mathrm{PM}_{2.5}$ at the $\mathrm{ND}$ site were higher than the $\mathrm{WHO}$ guideline (except for the $8^{\text {th }}$ event). For the RES site, the concentrations of $\mathrm{PM}_{2.5}$ during the $1^{\text {st }}, 6-9^{\text {th }}$, and $10^{\text {th }}$ events were higher than the WHO guideline. Therefore, the $\mathrm{PM}_{10}$ and $\mathrm{PM}_{2.5}$ levels in this study indicated a moderate level of pollution that could cause adverse effects on public health.

Among the 10 sampling events, three (upper 30\%) were regarded 


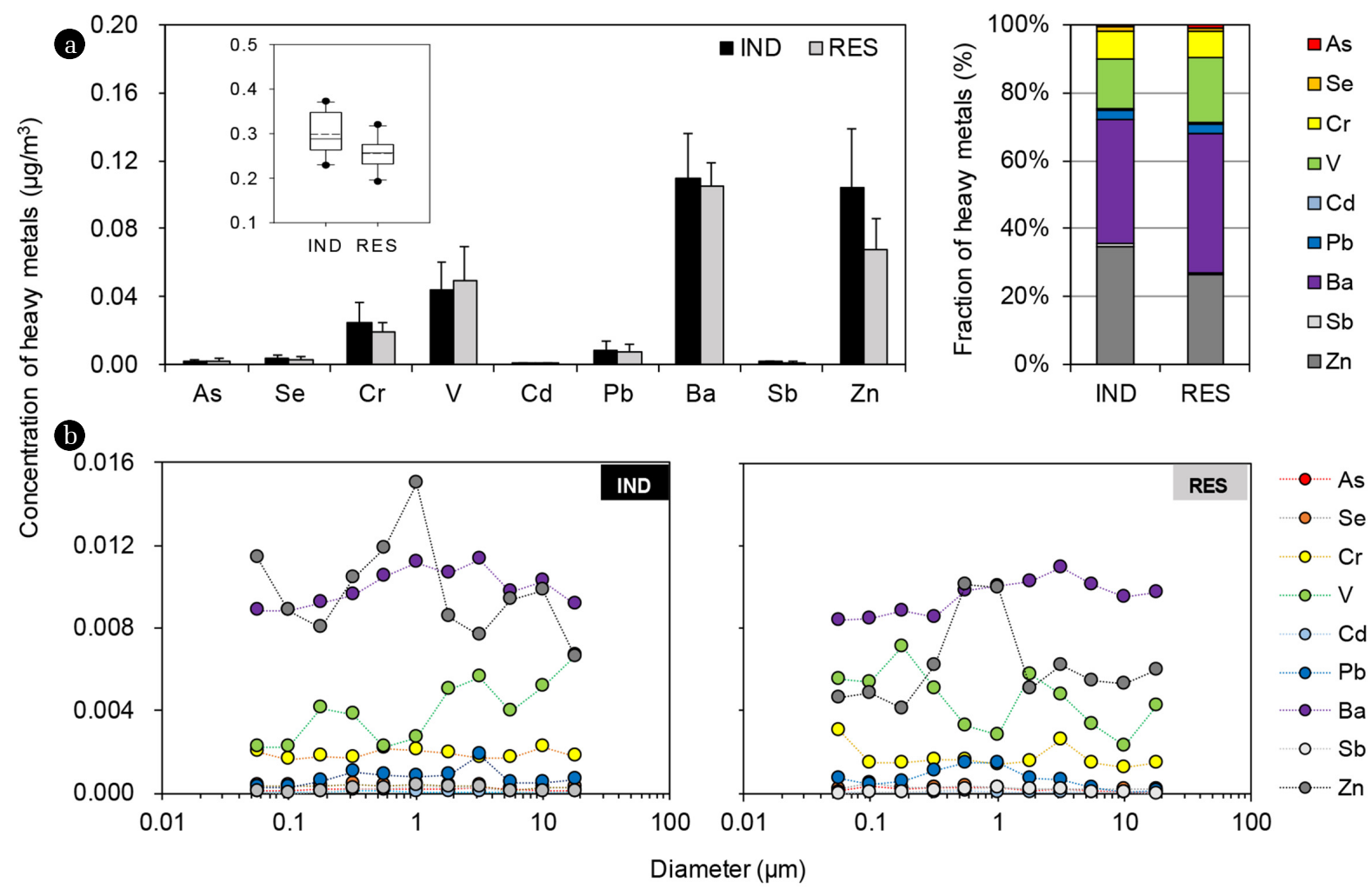

Fig. 3. Concentrations of trace metals associated with PM at each site: (a) mean concentrations of each trace metal in TPM (left) and mean fractions (right), and (b) mean concentrations of each trace metal in the given particle-size ranges.

as high-concentration events. The mean concentrations of TPM during the high-concentration events at the IND and RES sites were 62.0 and $49.0 \mu \mathrm{g} / \mathrm{m}^{3}$, respectively. According to the PM size distributions, stage $2(10-18 \mu \mathrm{m})$ at the IND site and stage $8(3.2-5.6 \mu \mathrm{m})$ at the RES site showed the highest concentrations. The fractions of super-micrometer $(>1 \mu \mathrm{m}) \mathrm{PM}$ at both sites exceeded $50 \%$ (62\% at the IND site and $56 \%$ at the RES site).

Overall, we found similar total concentrations of sub-micrometer $(<1 \mu \mathrm{m})$ PM during the high-concentration events (mean of both sites: $22.4 \mu \mathrm{g} / \mathrm{m}^{3}$ ) and during all the sampling events (mean of both sites: $20.8 \mu \mathrm{g} / \mathrm{m}^{3}$ ). Meanwhile, the concentrations of super-micrometer $(>1 \mu \mathrm{m}) \mathrm{PM}$ during the high-concentration events (mean of both sites: $33.1 \mu \mathrm{g} / \mathrm{m}^{3}$ ) were higher than the concentrations of all the events (mean of both sites: $26.7 \mu \mathrm{g} / \mathrm{m}^{3}$ ). The reasons for the higher concentrations of super-micrometer $\mathrm{PM}$ at the IND site might be due to road dust raised by heavy-duty vehicles or sea salt. However, the wind directions suggest that road dust is a more probable explanation. Industrial combustion and fugitive emissions from the petrochemical industrial complex are the main PM source in Ulsan, with much larger emissions of $\mathrm{PM}_{10}$ than $\mathrm{PM}_{2.5}$ [28]. This emission property can be an additional reason for the higher fractions of super-micrometer PM at the IND site.

\subsection{Trace Metals Associated with Total Particulate Matter}

Fig. 3 shows the concentrations of trace metals associated with PM. The total concentrations of nine trace metals $\left(\Sigma_{9}\right.$ metals $)$ in the TPM were $0.23-0.37 \mu \mathrm{g} / \mathrm{m}^{3}$ (mean: $0.30 \mu \mathrm{g} / \mathrm{m}^{3}$, median: $0.29 \mu \mathrm{g} / \mathrm{m}^{3}$ ) at the IND site and $0.19-0.32 \mu \mathrm{g} / \mathrm{m}^{3}$ (mean: $0.26 \mu \mathrm{g} / \mathrm{m}^{3}$, median: $0.26 \mu \mathrm{g} / \mathrm{m}^{3}$ ) at the RES site. The concentrations of individual trace metals (As, $\mathrm{Cr}, \mathrm{Cd}$, and $\mathrm{Pb}$ ) were comparable with the data from the national heavy metal monitoring network [21]. The other metals were not analyzed from the national monitoring network. The mean concentration of $\Sigma_{9}$ metals at the IND site was 1.2 times higher than the concentration at the RES site. A statistical difference exists between the two sites ( $t$-test, $p<0.05$ ). Most trace metals (except for $\mathrm{V}$ ) appeared at higher levels at the IND site than at the RES site, but only Zn showed a significant difference ( $t$-test, $p<0.01)$. Compared with TPM, the difference in metals between the two sites is relatively small. The reasons for this observation could be different daily wind patterns, elevations (IND: $21 \mathrm{~m}$, RES: $127 \mathrm{~m}$ ), and unknown emission sources. A long-term monitoring study is required to interpret this phenomenon.

The concentrations of $\mathrm{Ba}, \mathrm{Zn}, \mathrm{V}$, and $\mathrm{Cr}$ were much higher than the concentrations of other metals, with fractions of the sum of the four metals over $80 \%$ at both sampling sites during all the sampling events. The mean fractions of As, Se, Cd, and $\mathrm{Sb}$ were below $1 \%$, and $\mathrm{Pb}$ accounted for less than $3 \%$ of the total metal concentration at both sites. Furthermore, the concentrations of $\mathrm{As}, \mathrm{Cd}$, and $\mathrm{Pb}$ were much lower than the air quality guidelines: As (24 h, $3.0 \mu \mathrm{g} / \mathrm{m}^{3}$ ), Cd (annual, $10-20 \mathrm{ng} / \mathrm{m}^{3}$ ) and $\mathrm{Pb}$ (annual, 0.5-1.0 $\mu \mathrm{g} / \mathrm{m}^{3}$ ) [29]. Therefore, the four metals (Ba, $\mathrm{Zn}, \mathrm{V}$, and $\mathrm{Cr}$ ) were further considered, and their levels and 
Table 2. Mean Concentrations of Nine Trace Metals in Particle Size Ranges at Two Sampling Sites during the 10 Sampling Events

\begin{tabular}{|c|c|c|c|c|c|c|c|c|c|c|c|c|}
\hline \multirow{2}{*}{\multicolumn{2}{|c|}{$\left(\mathrm{ng} / \mathrm{m}^{3}\right)$}} & Stage 1 & Stage 2 & Stage 3 & Stage 4 & Stage 5 & Stage 6 & Stage 7 & Stage 8 & Stage 9 & Stage 10 & Stage 11 \\
\hline & & $18<$ & $10-18$ & 5.6-10 & $3.2-5.6$ & 1.8-3.2 & $1.0-1.8$ & $0.56-1.0$ & $0.32-0.56$ & 0.18-0.32 & 0.10-0.18 & $0.056-0.10$ \\
\hline \multirow{9}{*}{ IND } & As & 0.11 & 0.13 & 0.18 & 0.24 & 0.20 & 0.19 & 0.19 & 0.22 & 0.16 & 0.12 & 0.09 \\
\hline & Se & 0.27 & 0.30 & 0.13 & 0.31 & 0.33 & 0.40 & 0.38 & 0.44 & 0.33 & 0.31 & 0.36 \\
\hline & $\mathrm{Cr}$ & 1.80 & 2.21 & 1.72 & 1.67 & 1.95 & 2.04 & 2.14 & 1.73 & 1.79 & 1.62 & 2.02 \\
\hline & $\mathrm{V}$ & 6.67 & 5.17 & 3.93 & 5.57 & 4.98 & 2.63 & 2.23 & 3.80 & 4.13 & 2.19 & 2.22 \\
\hline & $\mathrm{Cd}$ & 0.05 & 0.05 & 0.03 & 0.05 & 0.06 & 0.07 & 0.08 & 0.09 & 0.07 & 0.06 & 0.04 \\
\hline & $\mathrm{Pb}$ & 0.61 & 0.53 & 0.52 & 1.83 & 0.87 & 0.77 & 0.90 & 1.03 & 0.60 & 0.24 & 0.24 \\
\hline & $\mathrm{Ba}$ & 9.12 & 10.2 & 9.76 & 11.3 & 10.6 & 11.2 & 10.5 & 9.54 & 9.19 & 8.86 & 8.80 \\
\hline & $\mathrm{Sb}$ & 0.06 & 0.07 & 0.05 & 0.26 & 0.27 & 0.32 & 0.20 & 0.19 & 0.07 & 0.00 & 0.02 \\
\hline & $\mathrm{Zn}$ & 6.56 & 9.78 & 9.34 & 7.64 & 8.55 & 14.9 & 11.8 & 10.4 & 8.03 & 8.81 & 11.4 \\
\hline \multirow{9}{*}{ RES } & As & 0.07 & 0.07 & 0.11 & 0.17 & 0.17 & 0.25 & 0.28 & 0.27 & 0.18 & 0.35 & 0.10 \\
\hline & Se & 0.17 & 0.20 & 0.21 & 0.21 & 0.22 & 0.32 & 0.33 & 0.32 & 0.26 & 0.54 & 0.17 \\
\hline & $\mathrm{Cr}$ & 1.48 & 1.26 & 1.48 & 2.61 & 1.54 & 1.43 & 1.67 & 1.64 & 1.50 & 1.48 & 3.04 \\
\hline & $\mathrm{V}$ & 4.29 & 2.30 & 3.38 & 4.79 & 5.72 & 2.86 & 3.25 & 5.08 & 7.08 & 5.42 & 5.54 \\
\hline & $\mathrm{Cd}$ & 0.03 & 0.03 & 0.03 & 0.05 & 0.04 & 0.07 & 0.10 & 0.08 & 0.06 & 0.05 & 0.03 \\
\hline & $\mathrm{Pb}$ & 0.10 & 0.09 & 0.28 & 0.67 & 0.76 & 1.47 & 1.46 & 1.12 & 0.58 & 0.45 & 0.73 \\
\hline & $\mathrm{Ba}$ & 9.72 & 9.53 & 10.1 & 10.9 & 10.2 & 10.0 & 9.82 & 8.56 & 8.87 & 8.48 & 8.38 \\
\hline & $\mathrm{Sb}$ & 0.02 & 0.04 & 0.04 & 0.18 & 0.20 & 0.25 & 0.20 & 0.14 & 0.07 & 0.06 & ND \\
\hline & $\mathrm{Zn}$ & 5.96 & 5.33 & 5.47 & 6.23 & 5.09 & 9.95 & 10.13 & 6.18 & 4.08 & 4.84 & 4.62 \\
\hline
\end{tabular}

ND: Not Detected.

possible emission sources are discussed in the following paragraphs.

The mean concentrations of Ba were very similar at both sites: 0.110 and $0.105 \mu \mathrm{g} / \mathrm{m}^{3}$ at the IND and RES sites, respectively. The similar concentrations and temporal variations (irrespective of sampling events at both sites) may be explained by identical emission sources, such as diesel vehicles using $\mathrm{Ba}$ as a fuel additive [30] and catalytic filters [31, 32]. Furthermore, transport equipment and machinery manufacturing is known as an important source of Ba in Korea [33].

In this study, most metals showed rather similar levels at both sampling sites. However, $\mathrm{Zn}$ was detected at concentrations 1.7 times (maximum 3.7 times) higher at the IND site (mean: 0.104 $\mu \mathrm{g} / \mathrm{m}^{3}$, median: $0.101 \mu \mathrm{g} / \mathrm{m}^{3}$ ) than at the RES site (mean: 0.068 $\mu \mathrm{g} / \mathrm{m}^{3}$, median: $0.066 \mu \mathrm{g} / \mathrm{m}^{3}$ ). The higher concentration of $\mathrm{Zn}$ at the IND site can be explained by the direct influence of industrial activities at the nearby stainless-steel factories [34] and by traffic emissions (i.e., tire-wear particles [35] and discharge from automotive brake pads [36]). In addition, metal smelting, plating, and alloys in non-ferrous industries can be an important source of Zn [37].

The mean concentrations of $\mathrm{Cr}$ at the IND and RES sites were $0.025 \mu \mathrm{g} / \mathrm{m}^{3}$ (median: $0.021 \mu \mathrm{g} / \mathrm{m}^{3}$ ) and $0.019 \mu \mathrm{g} / \mathrm{m}^{3}$ (median: 0.018 $\mu \mathrm{g} / \mathrm{m}^{3}$ ), respectively. Cr is classified as Group 1 (carcinogenic to human) by the International Agency for Research on Cancer (IARC). Cr is known to be directly emitted from steel and refractory industries [38]. In addition, coal combustion can increase Cr levels [7]. Indeed, a strong influence of coal combustion from the non-fer- rous industrial complex in Ulsan was reported in our previous study [39].

$\mathrm{V}$ is classified as Group 2B (possibly carcinogenic to human) by the IARC and is mostly emitted by oil combustion [40, 41]. The mean concentrations of $\mathrm{V}$ were $0.044 \mu \mathrm{g} / \mathrm{m}^{3}$ (median: 0.042 $\mu \mathrm{g} / \mathrm{m}^{3}$ ) at the IND site and $0.050 \mu \mathrm{g} / \mathrm{m}^{3}$ (median: $0.043 \mu \mathrm{g} / \mathrm{m}^{3}$ ) at the RES site. The similar levels at both sites were due to the last sampling event showing the highest V concentration. Some industrial facilities presumably using heavy oil are located north of the RES site, and northern winds were prevailing during this sampling event, which suggests that these winds were responsible for the higher concentrations of $\mathrm{V}$ at the RES site. However, this conclusion could not be confirmed because of the lack of emission data from the industrial facilities located north of the sampling site.

\subsection{Trace Metals in Particle-size Ranges}

The mean concentration and distribution patterns of nine trace metals across the particle-size ranges were generally similar (except for Zn and V). For the IND site, the highest concentration of $\mathrm{Sb}$ and $\mathrm{Zn}$ occurred in stage $6(1.0-1.8 \mu \mathrm{m})$. As, $\mathrm{Pb}$, and $\mathrm{Ba}$ appeared strongly in stage $4(3.2-5.6 \mu \mathrm{m})$, whereas $\mathrm{Cr}$ and V showed the highest levels in stage $2(10-18 \mu \mathrm{m})$ and stage $1(>18 \mu \mathrm{m})$, respectively. Therefore, most trace metals (except for Se and Cd) showed higher concentrations in super-micrometer PM, accounting for more than $50 \%$ of the total concentration. Meanwhile, for the RES site, $\mathrm{Pb}$ and $\mathrm{Sb}$ showed the highest levels in stage 
6 (1.0-1.8 $\mu \mathrm{m})$, whereas Ba occurred strongly in stage 4 (3.2-5.6 $\mu \mathrm{m})$. The fractions of $\mathrm{Ba}, \mathrm{Sb}, \mathrm{Zn}$, and $\mathrm{Cr}$ in super-micrometer PM exceeded $50 \%$ of the total concentration, whereas the other metals accumulated more in sub-micrometer PM. In brief, the concentrations of individual trace metals in each particle-size range were rather similar, but their size distribution differed between the two sampling sites.

For the high-concentration events (upper $30 \%$ of TPM), the concentrations of each trace metal were also similar regardless of the particle-size distribution (except for Zn and V). For Zn, stage $6\left(0.015\right.$ and $\left.0.015 \mu \mathrm{g} / \mathrm{m}^{3}\right)$ and stage 7 (0.011 and 0.016 $\mu \mathrm{g} / \mathrm{m}^{3}$ ) showed the highest concentrations measured from the IND and RES sites, respectively. The highest concentrations of $\mathrm{Zn}$ at both sites were four times higher than the lowest concentrations. The concentration of $\mathrm{V}$ in stage $1(>18 \mu \mathrm{m})$ was five times higher than the lowest concentration in stage 11. In addition, each trace metal in $\mathrm{PM}_{2.5}$ (stages 5-11) and $\mathrm{PM}_{10}$ (stages 2-11) contributed more than $50 \%$ and $90 \%$, respectively, of their total concentration in TPM at both sampling sites. Therefore, trace metals associated with respirable particles may affect the respiratory system, and higher TPM levels along with trace metals can have significant adverse effects on public health because of their synergistic effects.

\section{Conclusions}

The size distributions of PM and associated nine trace metals in Ulsan, South Korea were analyzed. We used MOUDIs in Ulsan for the first time and reports the highest particle-size resolution data. A weak bimodal distribution of PM was found, and the levels of PM and trace metals were generally higher at the IND site. The level of $\mathrm{PM}_{10}$ and $\mathrm{PM}_{2.5}$ indicated moderate pollution based on international standard guidelines. The concentrations of $\Sigma_{9}$ metals in TPM were higher at the IND site than at the RES site. Among the target metals, Ba, Zn, V, and Cr were dominant, which is attributed to industrial emissions and the accompanying traffic of heavy-duty vehicles. They have not been monitored in the national heavy metal monitoring network, except Cr. On the basis of this study, therefore, local source-receptor relationships of trace metals can be further investigated. Note that the high fractions of trace metals in respirable particles in this study (50\% and $90 \%$ in $\mathrm{PM}_{2.5}$ and $\mathrm{PM}_{10}$ ) may have adverse synergistic effects on public health. Thus, further intensive monitoring of the size distributions of other various pollutants (e.g., persistent organic pollutants and polycyclic aromatic hydrocarbons) are required to better understand the impact of PM on public health.

\section{Acknowledgments}

This work was supported by the National Research Foundation of Korea (NRF-2017R1A2B4003229 and 2017M3D8A1092015) and the National Institute of Environmental Research (NIER). We acknowledge Won-Joon Choi at NIER for the help of sampling and Ezaz Ahmed for constructive comments.

\section{References}

1. Taiwo AM, Beddows DCS, Shi Z, Harrison RM. Mass and number size distributions of particulate matter components: Comparison of an industrial site and an urban background site. Sci. Total Environ. 2014;475:29-38.

2. Zhang R, Jing J, Tao J, et al. Chemical characterization and source apportionment of $\mathrm{PM}_{2.5}$ in Beijing: Seasonal perspective. Atmos. Chem. Phys. 2013;13:7053-7074.

3. Chu HJ, Yu HL, Kuo YM. Identifying spatial mixture distributions of $\mathrm{PM}_{2.5}$ and $\mathrm{PM}_{10}$ in Taiwan during and after a dust storm. Atmos. Environ. 2012;54:728-737.

4. Beuck H, Quass U, Klemm O, Kuhlbusch TAJ. Assessment of sea salt and mineral dust contributions to $\mathrm{PM}_{10}$ in $\mathrm{NW}$ Germany using tracer models and positive matrix factorization. Atmos. Environ. 2011;45:5813-5821.

5. Pitz M, Gu J, Soentgen J, Peters A, Cyrys J. Particle size distribution factor as an indicator for the impact of the Eyjafjallajökull ash plume at ground level in Augsburg, Germany. Atmos. Chem. Phys. 2011;11:9367-9374.

6. Slezakova K, Morais S, Pereira MdC. Forest fires in Northern region of Portugal: Impact on PM levels. Atmos. Res. 2013;127: 148-153.

7. Wang J, Hu Z, Chen Y, Chen Z, Xu S. Contamination characteristics and possible sources of $\mathrm{PM}_{10}$ and $\mathrm{PM}_{2.5}$ in different functional areas of Shanghai, China. Atmos. Environ. 2013;68: 221-229.

8. Jones AM, Harrison RM. Emission of ultrafine particles from the incineration of municipal solid waste: A review. Atmos. Environ. 2016;140:519-528.

9. Squizzato S, Masiol M, Brunelli A, et al. Factors determining the formation of secondary inorganic aerosol: A case study in the Po Valley (Italy). Atmos. Chem. Phys. 2013;13:1927-1939.

10. Hallquist M, Wenger J, Baltensperger $U$, et al. The formation, properties and impact of secondary organic aerosol: Current and emerging issues. Atmos. Chem. Phys. 2009;9:5155-5236.

11. Al-Taani AA, Howari FM, Nazzal Y, Yousef A. Seasonal impact to air qualities in industrial areas of the Arabian Gulf region. Environ. Eng. Res. 2018;23:143-149.

12. Wall SM, John W, Ondo JL. Measurement of aerosol size distributions for nitrate and major ionic species. Atmos. Environ. 1988;22:1649-1656.

13. Park SS, Wexler AS. Size-dependent deposition of particles in the human lung at steady-state breathing. J. Aerosol Sci. 2008;39:266-276.

14. Reyes-Zárate E, Sánchez-Pérez Y, Gutiérrez-Ruiz MC, et al. Atmospheric particulate matter $\left(\mathrm{PM}_{10}\right)$ exposure-induced cell cycle arrest and apoptosis evasion through STAT3 activation via PKC $\zeta$ and Src kinases in lung cells. Environ. Pollut. 2016;214:646-656.

15. Valiulis D, Šakalys J, Plauškaite K. Heavy metal penetration into the human respiratory tract in vilnius. Lith. J. Phys. 2008;48:349-355.

16. Morawska L, Bofinger ND, Kocis L, Nwankwoala A. Submicrometer and supermicrometer particles from diesel vehicle emissions. Environ. Sci. Technol. 1998;32:2033-2042.

17. Xu J, Wang Z, Yu G, Qin X, Ren J, Qin D. Characteristics 
of water soluble ionic species in fine particles from a high altitude site on the northern boundary of Tibetan Plateau: Mixture of mineral dust and anthropogenic aerosol. Atmos. Res. 2014;143:43-56.

18. Allen AG, Nemitz E, Shi JP, Harrison RM, Greenwood JC. Size distributions of trace metals in atmospheric aerosols in the United Kingdom. Atmos. Environ. 2001;35:4581-4591.

19. Kim D-J, Shin H-J, Ahn B-K, Lee J-H. Competitive adsorption of thallium in different soils as influenced by selected counter heavy metals. Appl. Biol. Chem. 2016;59:695-701.

20. Nguyen TNT, Jung K-S, Son JM, Kwon H-O, Choi S-D. Seasonal variation, phase distribution, and source identification of atmospheric polycyclic aromatic hydrocarbons at a semi-rural site in Ulsan, South Korea. Environ. Pollut. 2018;236:529-539.

21. NIER. Annual report of air quality. Ministry of Environment, Inchon, Korea; 2015.

22. Ny MT, Lee B-K. Size distribution of airborne particulate matter and associated metallic elements in an urban area of an industrial city in Korea. Aerosol Air Qual. Res. 2011:643-653.

23. Lee BK, Hieu NT. Seasonal variation and sources of heavy metals in atmospheric aerosols in a residential area of Ulsan, Korea. Aerosol Air Qual. Res. 2011;11:679-688.

24. Hu J, Wang Y, Ying Q, Zhang H. Spatial and temporal variability of $\mathrm{PM}_{2.5}$ and $\mathrm{PM}_{10}$ over the North China Plain and the Yangtze River Delta, China. Atmos. Environ. 2014;95:598-609.

25. Huang W, Long E, Wang J, Huang R, Ma L. Characterizing spatial distribution and temporal variation of $\mathrm{PM}_{10}$ and $\mathrm{PM}_{2.5}$ mass concentrations in an urban area of Southwest China. Atmos. Pollut. Res. 2015;6:842-848.

26. Roy D, Singh G, Yadav P. Identification and elucidation of anthropogenic source contribution in $\mathrm{PM}_{10}$ pollutant: Insight gain from dispersion and receptor models. J. Environ. Sci. 2016.

27. Jancsek-Turóczi B, Hoffer A, Nyírő-Kósa I, Gelencsér A. Sampling and characterization of resuspended and respirable road dust. J. Aerosol Sci. 2013;65:69-76.

28. NIER. National air pollutants emission. Ministry of Environment, Inchon, Korea; 2016.
29. WHO. Evolution of WHO air quality guidelines: Past, present and future. World Health Organization, Copenhagen, Denmark; 2017.

30. Ribeiro NM, Pinto AC, Quintella CM, et al. The role of additives for diesel and diesel blended (ethanol or biodiesel) fuels: A review. Energ. Fuel. 2007;21:2433-2445.

31. Milt VG, Querini CA, Miró EE, Ulla MA. Abatement of diesel exhaust pollutants: $\mathrm{NO}_{\mathrm{x}}$ adsorption on $\mathrm{Co}, \mathrm{Ba}, \mathrm{K} / \mathrm{CeO}_{2}$ catalysts. J. Catal. 2003;220:424-432.

32. Pisarello ML, Milt VG, Peralta MA, Querini CA, Miró EE. Catalytic abatement of pollutants from diesel exhausts. Lat. Am. Appl. Res. 2003;33:345-352.

33. MOE. PRTR (Pollutant Release and Transfer Registers). Ministry of Environment, Sejong, Korea; 2014.

34. Fernández-Olmo I, Andecochea C, Ruiz S, Fernández-Ferreras JA, Irabien A. Local source identification of trace metals in urban/industrial mixed land-use areas with daily $\mathrm{PM}_{10}$ limit value exceedances. Atmos. Res. 2016;171:92-106.

35. Councell TB, Duckenfield KU, Landa ER, Callender E. Tire-wear particles as a source of zinc to the environment. Environ. Sci. Technol. 2004;38:4206-4214.

36. Whiley AJ. Copper and zinc loading associated with automotive brake-pad and tire wear. Washington State Department of Ecology, Olympia, Washington; 2011.

37. Emsley J. Nature's building blocks: An A-Z guide to the elements. Oxford: Oxford University Press; 2001.

38. EPA. Locating and estimation air emissions from sources of chromium. United States Environmental Protection Agency, Research Triangle Park, North Carolina; 1984.

39. Kwon H-O, Choi S-D. Polycyclic aromatic hydrocarbons (PAHs) in soils from a multi-industrial city, South Korea. Sci. Total Environ. 2014;470-471:1494-1501.

40. Lopez JM, Callen MS, Murillo R, et al. Levels of selected metals in ambient air $\mathrm{PM}_{10}$ in an urban site of Zaragoza (Spain). Environ. Res. 2005;99:58-67.

41. Ganor E, Altshuller S, Foner HA, Brenner S, Gabbay J. Vanadium and nickel in dustfall as indicators of power plant pollution. Water Air Soil Pollut. 1988;42:241-252. 